\title{
A Review of using Spray Pyrolysis through Sol-gel Materials in the Synthesis of Cathode Materials for Lithium-ion Batteries
}

\author{
Charmelle D. Snyders $^{a, *}$, Ernst E. Ferg ${ }^{a}$, Julian Schuelein ${ }^{b, c}$ and Holger Loewe \\ ${ }^{a}$ Department of Chemistry, Nelson Mandela Metropolitan University, P.O. Box 77000, Port Elizabeth, 6031, South Africa. \\ ${ }^{b}$ Institute of Organic Chemistry, Johannes Gutenberg University, Duesbergweg 10-14, 55128 Mainz, Germany. \\ ${ }^{c}$ Fraunhofer ICT-IMM, Carl-Zeiss-Str. 18-20, 55129 Mainz, Germany.
}

Received 3 July 2015, revised 30 March 2016, accepted 30 March 2016.

\begin{abstract}
Over the years, new synthesis routes of the cathode electrochemical active material for lithium-ion batteries have improved remarkably to optimize their capacity and cycle life performance. This review study focused on the use of some techniques to synthesize the common cathode materials $\left(\mathrm{LiCoO}_{2}, \mathrm{LiMn}_{2} \mathrm{O}_{4}, \mathrm{LiFePO}_{4}\right)$. The most common and simplest synthesis method was the mixing of powders in their solid-state form and heating them at relatively high temperatures over long periods. Other methods included the formation of sol-gel products that could be either heat-treated more or could be used directly by means of a spray pyrolysis method producing the desired active material. The spray pyrolysis method showed that suitable cathode oxide materials formed in shorter periods, resulting in small homogenous particles with narrow particle size distribution. The spray pyrolysis method allowed for making doped or coated cathode materials easily of the various base forms $\mathrm{LiCoO}_{2} \mathrm{LiMn}_{2} \mathrm{O}_{4}$ and $\mathrm{LiFePO}_{4}$, with doping elements such as $\mathrm{Zr}, \mathrm{Mn}, \mathrm{Ni}, \mathrm{Co}, \mathrm{B}$ or $\mathrm{Mg}$. Coating of the particles could also be done with materials such as glassy lithium boride oxide, $\mathrm{TiO}_{2}$ or carbon. These additives to the cathode material improved the active material's physical morphology and electrochemical properties.
\end{abstract}

KEYWORDS

$\mathrm{LiCoO}_{2}, \mathrm{LiMn}_{2} \mathrm{O}_{4}, \mathrm{LiFePO}_{4}$, sol-gel, spray pyrolysis method.

Table of Contents

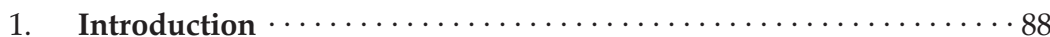

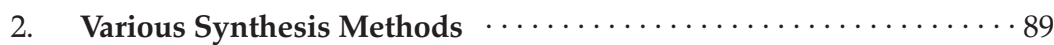

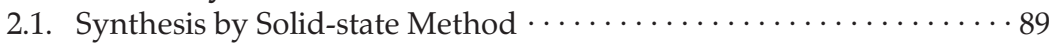

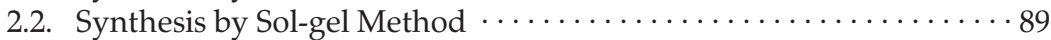

2.3. Synthesis by Spray Pyrolysis Method $\ldots \ldots \ldots \ldots \ldots \ldots \ldots \ldots \ldots \ldots \ldots \ldots$

3. Characterization of Materials made by Spray Pyrolysis Method ‥992

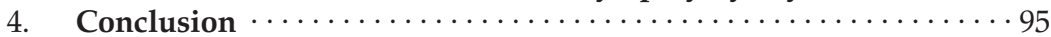

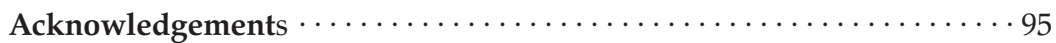

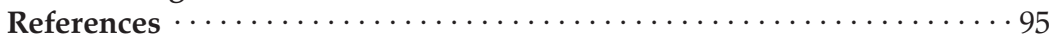

\section{Introduction}

The large-scale commercialization of lithium-ion cells can be dated back to the early 1990s with the development of modern portable consumer equipment, from wireless communications to mobile computing. ${ }^{1}$ The lithium-ion cell consists of an anode electrode (such as lithium metal or lithiated carbon supported onto a copper current collector), a cathode electrode (for example $\mathrm{LiCoO}_{2}, \mathrm{LiMn}_{2} \mathrm{O}_{4}$ or $\mathrm{LiFePO}_{4}$ supported onto an aluminium current collector $)^{1}$ immersed in non-aqueous or aprotic electrolytes consisting of lithium salts (such as $\mathrm{LiPF}_{6}, \mathrm{LiBF}_{4}$ or $\mathrm{LiClO}_{4}$ ) dissolved in an organic solvent (for example ethylene carbonate, dimethyl carbonate, or diethyl carbonate or a mixture of them)2. The anode and cathode electrodes are separated by a separator which was made of a porous membrane (such as cellulose, glass fibre, inorganic composite membranes and microporous polymer

* To whom correspondence should be addressed.

E-mail: charmelle.snyders@nmmu.ac.za membranes) to allow the ionic flow or transport of lithium-ions between the electrodes. ${ }^{3,4}$ Lithium-ion cells are manufactured and assembled in the discharge state (the lithium-ions are in the cathode's active material structure). The cell was first charged before it is sealed and packaged for commercial use. During the charging process lithium-ions are extracted from the lithium metal oxide structure and migrate through a porous separator with the aid of an electrolyte, into the anode active material (known as intercalation). Whereas upon discharge the lithiumions are extracted from the anode and embedded back into the vacant sites of the lithium metal oxide material's crystal structure (known as de-intercalation). Fig. 1 demonstrated the intercalation and de-intercalation processes taking place in a lithium-ion cell.

The synthesis process used to make the cathode oxide material for lithium-ion batteries has undergone a variety of changes in techniques that ranged from solid-state to sol-gel, co-precipitation, 


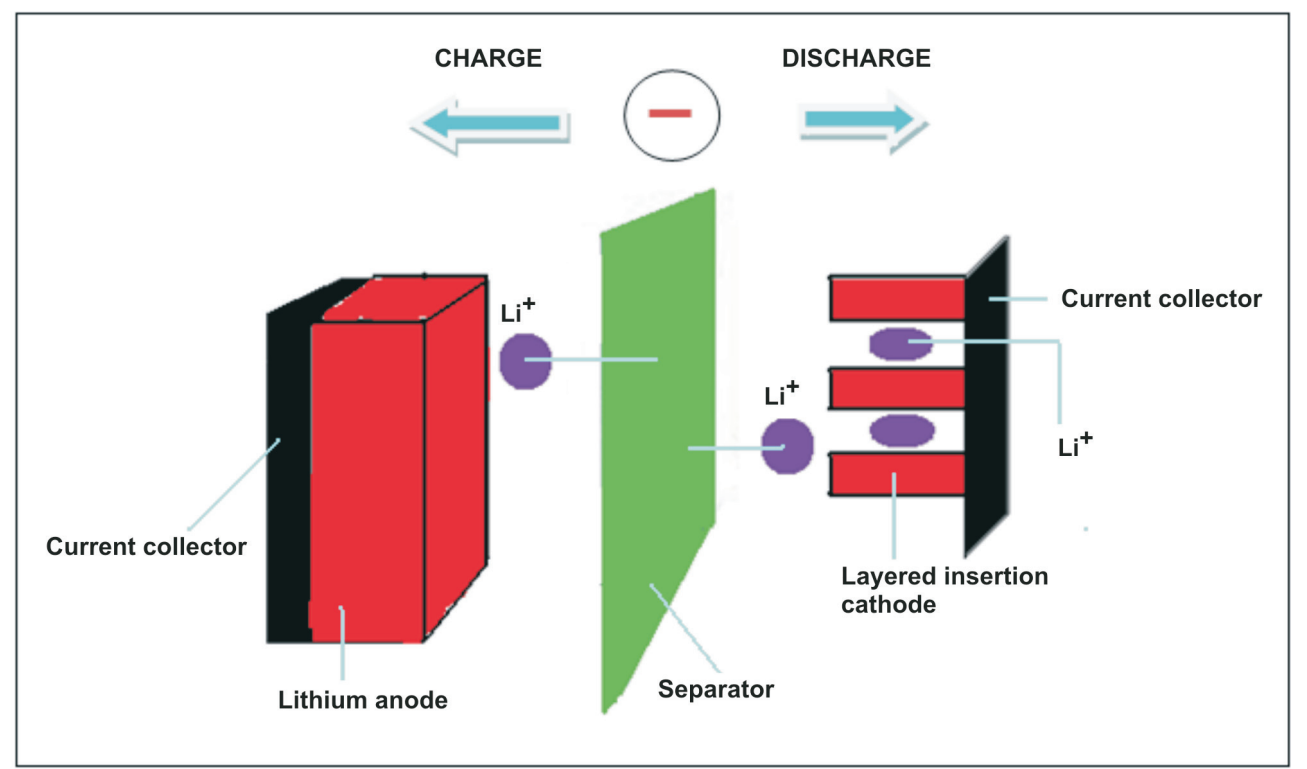

Figure 1 A schematic diagram on the insertion and extraction in lithium-ion cells.

combustion, spray pyrolysis, microwave and hydrothermal methods. ${ }^{5}$ Even though many of these methods have proved to be useful at laboratory-scale synthesis, the complexity and cost implications of scaling such methods to industrial manufacturing often proved to be unfeasible. Over the years one method, the spray pyrolysis method, proved to be successful at both laboratory-scale and industrial level of synthesizing. The spray pyrolysis method showed versatility in its approach to incorporate a variety of chemical compositions and techniques that can be scaled to industrial feasible processes with relative ease.

The present study reviewed the historical and current uses of the spray pyrolysis method on the synthesis of cathode oxide materials in lithium-ion (Li-ion) batteries. The traditional synthesis methods used at laboratory scale to make cathode materials for Li-ion batteries mainly comprised of solid-state reaction methods. The solid-state methods were applied by a relatively simple process of mixing the right ratios of solid powders containing the lithium-ion (usually $\mathrm{Li}_{2} \mathrm{CO}_{3}$ ) with a transition metal oxide such as $\mathrm{Mn}, \mathrm{Co}$ or $\mathrm{Ni}$. These elements were typically heated in an oxidizing atmosphere at high temperatures for a few hours. The processes were scaled with relative ease to industrial batch-size processes to obtain a relatively consistent product that met the requirements in application. These reaction processes were divided into two methods/categories (the dry solid-state and wet-milling methods), depending on the difference in pre-treatment. ${ }^{6}$ However, these methods had a number of disadvantages in both the cost of scaling and the consistency of the final prepared product. The disadvantages included a relatively large particle size distribution, long synthesis times at elevated temperatures, several mechanical mixing and grinding steps. ${ }^{6}$

\section{Various Synthesis Methods}

The different cathode oxide materials (such as $\mathrm{LiCoO}_{2}$, $\mathrm{LiMn}_{2} \mathrm{O}_{4}$ and $\mathrm{LiFePO}_{4}$ ) were synthesized following various synthesis techniques (including the solid-state, sol-gel and spray pyrolysis method), which are discussed in the sections that follow.

\subsection{Synthesis by Solid-state Method}

The well-known cobalt-based cathode material, $\mathrm{LiCoO}_{2}$, was synthesized by the solid-state method by mechanical mixing the right stoichiometric ratios of $\mathrm{Li}_{2} \mathrm{CO}_{3}$ and $\mathrm{CO}_{3} \mathrm{O}_{4}$, followed by heating the product at $850^{\circ} \mathrm{C}$ for 24 hours. Thereafter the product underwent further calcination at $650{ }^{\circ} \mathrm{C}$ for 12 hours in an air atmosphere. The final crystalline reaction product was ground and stored in a desiccator due to its hygroscopic nature. ${ }^{7}$

The typical synthesis of $\mathrm{LiMn}_{2} \mathrm{O}_{4}$ by solid-state reaction involved stoichiometric amounts of $\mathrm{Li}_{2} \mathrm{CO}_{3}$ and $\mathrm{MnO}_{2}$ as starting materials. These starting materials were ball milled and heated at $750{ }^{\circ} \mathrm{C}$ for 24 hours in an air atmosphere. The final product was ground at ambient temperature. ${ }^{8}$

For the synthesis of $\mathrm{LiFePO}_{4}$ by solid-state method, $\mathrm{LiF}, \mathrm{Li}_{2} \mathrm{CO}_{3}$, $\mathrm{LiOH} \cdot 2 \mathrm{H}_{2} \mathrm{O}$ or $\mathrm{CH}_{3} \mathrm{COOLi}$ were used as the lithium source, $\mathrm{FeC}_{2} \mathrm{O}_{4} \cdot 2 \mathrm{H}_{2} \mathrm{O}, \mathrm{Fe}\left(\mathrm{CH}_{3} \mathrm{COO}_{2}\right)_{2}$ or FePO $\mathrm{P}_{4}\left(\mathrm{H}_{2} \mathrm{O}\right)_{2}$ were used as the $\mathrm{Fe}$ source, and $\mathrm{NH}_{4} \mathrm{H}_{2} \mathrm{PO}_{4}$ or $\left(\mathrm{NH}_{4}\right)_{2} \mathrm{HPO}_{4}$ was used as the $\mathrm{PO}_{4}$ source. ${ }^{9}$ The method typically involved complete mixing of $\mathrm{Li}_{2} \mathrm{CO}_{3}, \mathrm{FeC}_{6} \mathrm{H}_{5} \mathrm{O}_{7} \cdot \mathrm{H}_{2} \mathrm{O}$ and $\mathrm{NH}_{4} \mathrm{H}_{2} \mathrm{PO}_{4}$ as starting materials in the right proportionate amounts in an acetone medium using a ball mill for 24 hours. The product was preheated in air at various temperatures: 200,300 and $400{ }^{\circ} \mathrm{C}$ for three hours. The samples were further calcined at $700^{\circ} \mathrm{C}$ in Ar gas for six hours, producing the final product. ${ }^{10}$ However, Kim et al. ${ }^{11}$ prepared this material slightly different, using an acetone solution of $\mathrm{FeC}_{2} \mathrm{O}_{4} \cdot 2 \mathrm{H}_{2} \mathrm{O}$, $\mathrm{Li}_{2} \mathrm{CO}_{3}$ and $\mathrm{NH}_{4} \mathrm{H}_{2} \mathrm{PO}_{4}$ that was ball milled for 24 hours followed by drying at $100^{\circ} \mathrm{C}$ for 12 hours. The product was decomposed by heating it at $350{ }^{\circ} \mathrm{C}$ for 10 hours in an Ar atmosphere. The dried product was pelletized and calcined at $600^{\circ} \mathrm{C}$ for 10 hours under Ar producing the final crystalline $\mathrm{LiFePO}_{4}{ }^{11}$ These four examples showed that the solid-state synthesis procedures were lengthy in time and high in energy consumption.

\subsection{Synthesis by Sol-gel Method}

Over the years various synthesis methods were developed not only to improve the performance of the material but also to reduce the energy required and the time involved in solid-state synthesis methods. The use of sol-gel chemistry was originally studied in 1846 by Ebelenen ${ }^{12}$ when he discovered that $\mathrm{SiO}_{2}$ gels could be formed through hydrolysing $\mathrm{Si}(\mathrm{OEt})_{4}$. However, it was only in 1930 that the sol-gel method developed further for commercial applications. ${ }^{12}$ The synthesis of silica by sol-gel method involved the hydrolysis and condensation of silicon alkoxides. The synthesis method could be explained as follows ${ }^{13}$ and summarized in Fig. 2.

$\mathrm{Si}-\mathrm{OR}+\mathrm{H}_{2} \mathrm{O} \quad \Rightarrow \mathrm{Si}-\mathrm{OH}+\mathrm{ROH}$ (hydrolysis) 


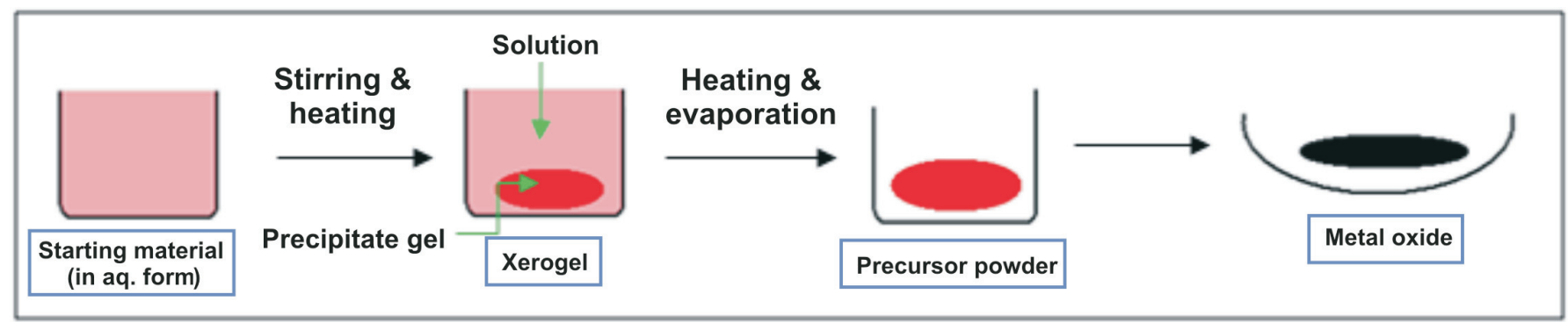

Figure 2 Schematic flow diagram of a typical sol-gel process.

$\mathrm{Si}-\mathrm{OH}+\mathrm{RO}-\mathrm{Si} \Rightarrow \mathrm{Si}-\mathrm{O}-\mathrm{Si}+\mathrm{ROH}$ (alcohol condensation) $\mathrm{Si}-\mathrm{OH}+\mathrm{Si}-\mathrm{OH} \Rightarrow \mathrm{Si}-\mathrm{O}-\mathrm{Si}+\mathrm{HOH}$ (water condensation) $\mathrm{Si}(\mathrm{OR})_{4}+2 \mathrm{H}_{2} \mathrm{O} \Rightarrow \mathrm{SiO}_{2}+4 \mathrm{ROH}$ (overall reaction)

The sol-gel method was further developed for the synthesis of a variety of glasses, ceramics, inorganic fillers and coatings. ${ }^{12}$ In some industrial applications, the coatings were used for chemical protection (such as corrosion inhibitors) and mechanical protection (such as abrasion resistance)..$^{14}$ The technology was also used in biomedical applications (such as biomedical sensors and coatings for metal implants) $)^{15,16}$ and is still used daily in various chemistries such as cosmetics (including sunscreen lotion and makeup with UV absorbers). ${ }^{16}$ The uniqueness of the sol-gel method was that it produced a homogeneous mixture in a solution that was almost at the atomic/molecular level. The stoichiometric amount could be controlled and the synthesis temperatures were relatively low in comparison to the solid-state method. Short heating rates by the sol-gel process could produce a good crystalline material with uniform particle sizes that had relatively smaller diameters. ${ }^{12}$ However, there were a number of disadvantages in using sol-gel methods that included the high cost of the raw material and a comparatively large volume shrinkage as a result of drying and sintering the material.

A number of cathode materials for Li-ion batteries were made by using the sol-gel method. The methods included the layered $\left(\mathrm{LiCoO}_{2}\right)$ structured material that was prepared by dissolving a cobalt salt (nitrate or acetate) in a suitable solvent such as water or ethanol. The carrier used to control the particle size and uniformity for dispensing ions in the solution was typically made of an organic compound that acted as a chelating agent (such as citric acid, polyacrylic acid, malic acid or oxalic acid) producing an aqueous solution. At this point, the $\mathrm{pH}$ of the solution had to be maintained producing an acidic solution (at about $\mathrm{pH} 4$ to $\mathrm{pH}$ 5.5 ) by the addition of an aqueous $\mathrm{LiOH}$ or ammonium solution. ${ }^{12,17}$ The solvent evaporated at about 70 to $100^{\circ} \mathrm{C}$, producing a viscous gel that was completely dried at about 140 to $400{ }^{\circ} \mathrm{C}$, producing a precursor powder. The precursor powder was heated between 500 and $800{ }^{\circ} \mathrm{C}$ in air with a 12-hour plateau producing the final metal oxide product. ${ }^{12,17,18}$ There have been recent developments in making the layered structured materials with new synthesis routes by doping the final material with various transition metal elements that included $\mathrm{Mg}, \mathrm{Cu}, \mathrm{Eu}$ or Co. ${ }^{19-22}$ In addition, the method was used to coat the active layered oxide with carbon and various metal oxides that included $\mathrm{Al}_{2} \mathrm{O}_{3}$ $\mathrm{MgO}, \mathrm{Li}_{2} \mathrm{CO}_{3}, \mathrm{AlPO}_{4}, \mathrm{SnO}_{2}{ }^{12,23}$ These new developments have shown improvements in reducing the manufacturing cost, increasing the active material's capacity and cycling ability, improving structural stability and improving the overall electrochemical properties of the batteries. ${ }^{12,23}$

The sol-gel synthesis process of the well-known spinel-type $\mathrm{LiMn}_{2} \mathrm{O}_{4}$ materials was typically made by dissolving the manganese and lithium salts (acetates) in stoichiometric amounts with a carrier (citric acid, ethylene glycol, polyacrylic acid, adipic acid or glycolic acid $)^{24-26}$ in water. The result was an aqueous solution where the $\mathrm{pH}$ was sometimes adjusted to a slightly basic form by adding ammonium hydroxide..$^{12,27-29}$ The aqueous solution was then heated to $120{ }^{\circ} \mathrm{C}$ with continuous stirring to form the gel-solid precipitate. Further heating resulted in the solid powder precursor which was completely dried at $140{ }^{\circ} \mathrm{C}$ for about five hours. The dried precursor was calcined at $750{ }^{\circ} \mathrm{C}$ for about 15 hours in an air atmosphere producing the final Li-metal oxide spinel cathode material. ${ }^{27}$ Modifications of the spinel material were done by doping the spinel material with various transition elements (only a few are mentioned such as $\mathrm{Mg}, \mathrm{Al}, \mathrm{Cr}, \mathrm{Co}$ and $\mathrm{Ni})^{27,30-32}$ and by surface coating (such as nano- $\mathrm{SiO}_{2}, \mathrm{Al}_{2} \mathrm{O}_{3}$ and carbon coating). ${ }^{33}$ These modifications helped to increase the electrochemical properties of the material, such as improvement in capacity retention and cycleability, improved interfacial properties between electrolyte and electrode, enhanced electrical conductivity and protecting the metal oxide from chemical corrosion..$^{33}$

The sol-gel synthesis method for synthesizing the olivine-type structure materials, of which the $\mathrm{LiFePO}_{4}$ is a typical example, consisted of various starting materials. For the Li component, the following salts could be used: $\mathrm{Li}(\mathrm{OH}) \cdot \mathrm{H}_{2} \mathrm{O}, \mathrm{LiNO}_{3}, \mathrm{LiCO}_{3}, \mathrm{Li}$ $\left(\mathrm{CH}_{3} \mathrm{COO}\right)$ or $\mathrm{Li}_{2} \mathrm{C}_{2} \mathrm{O}_{4} \cdot{ }^{34-37}$ For the Fe complex, $\mathrm{FeC}_{2} \mathrm{O}_{4} \cdot 2 \mathrm{H}_{2} \mathrm{O}$, Fe $\left(\mathrm{C}_{2} \mathrm{H}_{3} \mathrm{O}_{2}\right)$ or $\mathrm{C}_{6} \mathrm{H}_{5} \mathrm{FeO}_{7}{ }^{34-37}$ could be used, whereas the phosphate would be $\mathrm{NH}_{4} \cdot \mathrm{H}_{2} \mathrm{PO}_{4} \cdot{ }^{34,35}$ Two synthesis routes following the sol-gel process were discussed to show that the pure olivine structure could be formed regardless of the different starting materials. The first method involved dissolving stoichiometric amounts of $\mathrm{Li}(\mathrm{OH}) \cdot \mathrm{H}_{2} \mathrm{O}, \mathrm{FeC}_{2} \mathrm{O}_{4} \cdot 2 \mathrm{H}_{2} \mathrm{O}$ and $\mathrm{NH}_{4} \cdot \mathrm{H}_{2} \mathrm{PO}_{4}$ reagents in deionized water with polyacrylic or citric acid. ${ }^{34}$ Another synthesis procedure involved dissolving stoichiometric amounts of $\mathrm{NH}_{4} \cdot \mathrm{H}_{2} \mathrm{PO}_{4}, \mathrm{Fe}_{3} \mathrm{NO}_{3}$ and $\mathrm{LiNO}_{3}$ in a polyvinyl alcohol and ethanol-water $(50: 50 \mathrm{v} / \mathrm{v})$ solution..$^{35}$ Both these procedures resulted in a sol-gel at $80-85^{\circ} \mathrm{C}$ with vigorous stirring. The first procedure required drying the gel at about $500^{\circ} \mathrm{C}$ under Ar gas, decomposing all the organics present and heating the precursor up to $700{ }^{\circ} \mathrm{C}$ under a reducing gas mixture $\left(10 \% \mathrm{H}_{2}\right.$ in $\left.\mathrm{Ar}\right)$ resulting in the pure olivine structure. The second procedure however, required the gel to dry under a reducing atmosphere of a $\mathrm{H}_{2} / \mathrm{N}_{2}$ $(10 / 90)$ mixture until the gel dried completely. Thereafter, the precursor was heated at $675^{\circ} \mathrm{C}$ for four hours under the same atmospheric environment resulting in the olivine-structured material. The olivine-structured material was pyrolized or sintered in a controlled gas environment to prevent the formation of $\mathrm{Fe}^{2+}$ resulting in an increased yield of the olivine structure. Dopants were introduced to the material to improve the conductivity and cycle life by using ascorbic acid as the carrier with dissolved metals such as $\mathrm{Cu}$ or Ag. The metals were added in very low concentrations to improve the kinetics and conductivity of the final structured material. ${ }^{12}$

Other cathode materials for lithium-ion batteries were also 
prepared and studied using the sol-gel methods. The materials included a range of lithium vanadium oxides and lithium nickel oxides. The Li-ion intercalation into $\mathrm{V}_{2} \mathrm{O}_{5}$ was already recorded in $1976 .^{38} \mathrm{~V}_{2} \mathrm{O}_{5}$ was considered a cathode material because of its low cost, abundance and its ability to synthesize easily with a relatively high energy density. $\mathrm{V}_{2} \mathrm{O}_{5}$ had a layered crystal structure and therefore, it was a typical intercalation compound. However, due to the material's poor structural stability during the intercalation process, low electronic and ionic conductivity and slow electrochemical kinetics, the development of $\mathrm{V}_{2} \mathrm{O}_{5}$ as cathode in rechargeable lithium-ion batteries was limited. ${ }^{38}$ Using the solid-state method, lithium vanadium phosphate $\left(\mathrm{Li}_{3} \mathrm{~V}_{2}\left(\mathrm{PO}_{4}\right)_{3}\right)$ was synthesized by mixing appropriate amounts of $\mathrm{NH}_{4} \mathrm{H}_{2} \mathrm{PO}_{4}, \mathrm{~V}_{2} \mathrm{O}_{5}$ and $\mathrm{Li}_{2} \mathrm{CO}_{3}$. The prepared mixture was heated at $300{ }^{\circ} \mathrm{C}$ in air for four hours, allowing water and $\mathrm{NH}_{3}$ to evolve. The obtained product was ground, pelletized and heated at $850^{\circ} \mathrm{C}$ in an $\mathrm{H}_{2}$ atmosphere for eight hours. After furnace cooling, the product was ground, pelletized and heated again for another 16 hours (at $850^{\circ} \mathrm{C}$ ) to ensure complete final metal oxide formation. ${ }^{39} \mathrm{Li}_{3} \mathrm{~V}_{2}\left(\mathrm{PO}_{4}\right)_{3}$ prepared by the sol-gel method involved dissolving $\mathrm{LiOH} \cdot \mathrm{H}_{2} \mathrm{O}, \mathrm{NH}_{4} \mathrm{VO}_{3}, \mathrm{H}_{3} \mathrm{PO}_{4}$ and citric acid in distilled water while stirring continuously and maintaining the $\mathrm{pH}$ around 9 by adding $\mathrm{NH}_{3} \cdot \mathrm{H}_{2} \mathrm{O} .{ }^{40}$ The gel was formed by means of vacuum drying at $120{ }^{\circ} \mathrm{C}$ for eight hours. The dried gel was heated at $300{ }^{\circ} \mathrm{C}$ for three hours in air to remove water, $\mathrm{NH}_{3}$ and $\mathrm{CO}_{2}$ completely. The obtained product was calcined for eight hours at $700-900{ }^{\circ} \mathrm{C}$ in a reducing atmosphere $\left(8 \% \mathrm{H}_{2}\right.$ in $\left.\mathrm{Ar}\right) .{ }^{40}$ The electrochemical performances of this material showed an increase in cycling capacity with reasonably good capacity retention of about $95 \%{ }^{40}$

$\mathrm{LiNiO}_{2}$ was also used as a cathode material for Li-ion batteries. The cost of $\mathrm{LiNiO}_{2}$ was relatively lower than the cost of $\mathrm{LiCoO}_{2}$ and had a higher reversible capacity. The layered structure made it difficult to prepare the material on a large scale because of the $\mathrm{Ni}^{2+}$ to $\mathrm{Ni}^{3+}$ oxidation. ${ }^{12} \mathrm{LiNiO}_{2}$ had a lower degree of ordering (when compared to $\mathrm{LiCoO}_{2}$ ) when the nickel-ions occupied the sites in the lithium crystal planes causing difficulties to form the appropriate composition. ${ }^{41}$ The problems were solved by adding cobalt upon which the nickel-ion positions were occupied by the nickel/cobalt crystal plane, resulting in an increased degree of ordering. ${ }^{41}$ Following a sol-gel synthesis route, this cathode material was synthesized by making an aqueous solution consisting of lithium hydroxide, ammonium hydroxide, a nickel salt (such as nickel nitrate) and citric acid. The solution was stirred and the solvent was removed at a temperature below $100{ }^{\circ} \mathrm{C}$ to form a xero-gel. Crystalline $\mathrm{LiNiO}_{2}$ was formed by heating the obtained dry powder at above $400{ }^{\circ} \mathrm{C} .{ }^{12}$ The sol-gel synthesis method produced a good capacity retention material. Cobaltdoped $\mathrm{LiNiO}_{2}$ by means of sol-gel methods was prepared as follows: Stoichiometric nitrate amounts of lithium, cobalt and nickel were dissolved in a suitable solvent (such as water or ethanol) with chelating carrier agents (such as ascorbic acid, citric acid, maleic acid, oxalic acid or triethanolamine) $)^{12,42}$ The resulting solution was stirred at $80^{\circ} \mathrm{C}$. The obtained solution was heated further at $100^{\circ} \mathrm{C}$, producing a gel. The gel was dried at $100-200^{\circ} \mathrm{C}$ for two hours and at $240{ }^{\circ} \mathrm{C}$ for five hours. ${ }^{42}$ The dried precursor was calcined further for 12 hours at $800{ }^{\circ} \mathrm{C} .{ }^{12}$ The doped material stabilized $\mathrm{LiNiO}_{2}$ and improved the electrochemical properties.

\subsection{Synthesis by Spray Pyrolysis Method}

Spray pyrolysis combined with the development of sol-gel chemistry processes proved that it is necessary to synthesize powders of good quality, low moisture and a narrow particle size distribution. The technique was used for a variety of chemistry syntheses and could be adapted for either continuous or single-step preparation methods. The use of spray pyrolysis as a route for thermal synthesis of chemical materials was used in many industries for a variety of applications such as fuel cells ( $\mathrm{Pt}$ active material), foods (milk powder, cereal, coffee, tea), pharmaceuticals (antibiotics, medical active ingredients) and consumer goods (paint pigments, ceramic materials, catalyst supports). ${ }^{43,44}$ Besides the large number of advantages this technique displayed, it also had a few disadvantages. The technique was well suited for the synthesis of micro- or even nano-sized particles. However, an efficient separation technique was required for the production of these fine powders in order to avoid the loss of products and environmental pollution..$^{44}$ These processes often required high evaporation rates and usually took place within short residence times. The spray pyrolysis method was ideal for drying heat-sensitive materials but it was not suitable for materials that could conglomerate easily. The powders of the desired material were produced from a liquid or slurry mixture that was pumped through a set of nozzles after which it was dried rapidly with the aid of hot gases. Air was the preferred gas to use during the drying process. However, if the solvent or liquid was flammable and if the produced product was oxygensensitive, nitrogen gas was often used. The technique used spray nozzles or atomizers that could disperse the liquid into very finely controlled droplets. The gas used during the process, acted as a carrier, enabling the particles that were formed to undergo a significantly faster and uniform thermal reaction. The flow of the precursor solution was pumped, usually by a peristaltic pump, with a constant gas flow through a nozzle into a pre-heated heating apparatus. At this point, solvent evaporation took place rapidly and the dried mixed precursor powder was passed through a filtering system that collected the final desired active material. The final product of this process produced amorphous, semi crystalline or crystalline powders. ${ }^{45}$ A schematic diagram of the spraying process was shown in Fig. 3.

Using the spray pyrolysis process, ultrafine $\mathrm{LiCoO}_{2}$ could be synthesized in a short period. The method involved the use of an aqueous solution containing acetates of $\mathrm{Li}$ and $\mathrm{Co}$ with polyethylene glycol. The solution was pumped through a nozzle with pressurized hot air (at $0.1 \mathrm{MPa}$, a gas flow rate of $6.6 \mathrm{~L} \mathrm{~min}^{-1}$ and a residence time of $6 \mathrm{sec}$ ) into a heated apparatus at about $300^{\circ} \mathrm{C} .{ }^{46}$ The dried precursor material was formed followed by further calcining at $800{ }^{\circ} \mathrm{C}$ in air for four hours, producing the pure $\mathrm{LiCoO}_{2}{ }^{46}$

Spray pyrolysis techniques were used successfully to make pure cubic spinel $\mathrm{LiMn}_{2} \mathrm{O}_{4}$ hollow structures with a spherical shaped nanostructured particle with improvements to the electrochemical properties. ${ }^{47}$ The method involved the use of an aqueous reaction solution of $\mathrm{LiNO}_{3}$ and $\mathrm{Mn}\left(\mathrm{NO}_{3}\right)_{2} \cdot 6 \mathrm{H}_{2} \mathrm{O}$ in stoichiometric ratios that went through an ultrasonic atomizer (at $100 \mathrm{kHz}$ with a gas flow rate of $20 \mathrm{dm}^{3} \mathrm{~min}^{-1}$ and residence time of $60 \mathrm{sec}$ ) into a heated ceramic furnace at $800{ }^{\circ} \mathrm{C}$ for four hours in an air atmosphere. $^{47}$

Gomez et al. ${ }^{48}$ recorded the preparation of $\mathrm{LiFePO}_{4}$ material by means of the spray pyrolysis method. The method used a $0.01 \mathrm{M}$ precursor solution of $\mathrm{LiNO}_{3}, \mathrm{Fe}_{2} \mathrm{C}_{2} \mathrm{O}_{4} \cdot \mathrm{H}_{2} \mathrm{O}$ and $\mathrm{NH}_{4} \mathrm{H}_{2} \mathrm{PO}_{4}$ in nitric acid ( $\mathrm{pH}$ 1.5). An aerosol ultrasonic generator atomized the solution, with Ar as the carrier gas (with a flow rate of $1.5 \mathrm{~L} \mathrm{~min}^{-1}$ ) into fine droplets at $2.1 \mathrm{MHz}$. The droplets passed through a tubular flow reactor and thermally decomposed at 400 to $700^{\circ} \mathrm{C}$. The obtained powders were further heated for six hours in an $\mathrm{Ar}$ atmosphere at 600 to $800{ }^{\circ} \mathrm{C}$, obtaining the pure $\mathrm{LiFePO}_{4}$ phase. ${ }^{48}$ Companies such as Argonne National Laboratory (USA), who made nanoparticles of lithium titanates and spinel oxides, made 


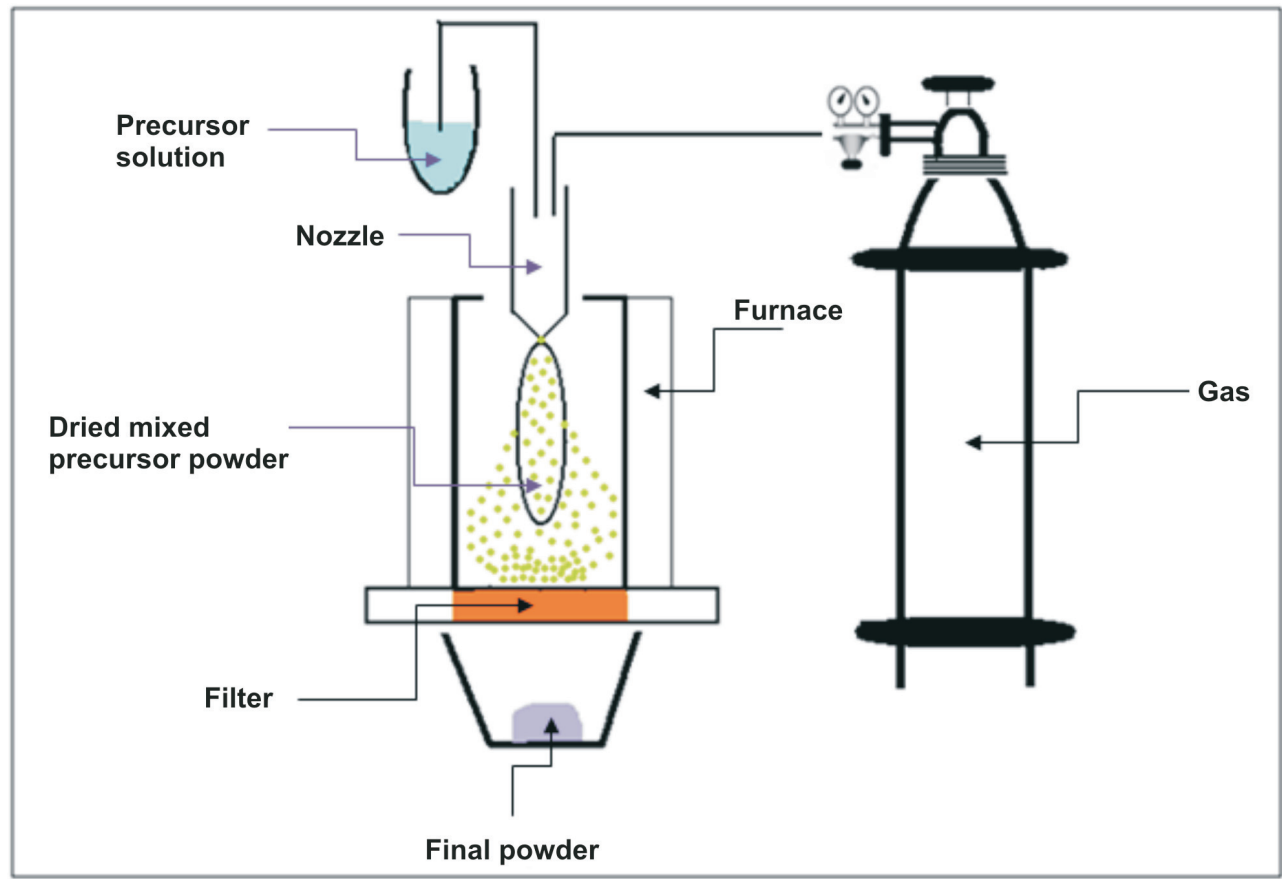

Figure 3 Schematic diagram on a typical spray drying process.

active cathode materials for Li-ion batteries by means of the commercial process of spray drying. They had a license agreement with BASF to produce and market these materials. ${ }^{49}$

\section{Characterization of Materials made by Spray Pyrolysis Method}

Li et al ${ }^{46}$ followed the spray pyrolysis technique for the $\mathrm{LiCoO}_{2}$ synthesis route and the scanning electron microscopy (SEM) analysis showed the formation of a relatively good distribution of homogeneous particles with a small grain size, with no agglomeration and an average particle size of between 200 and $700 \mathrm{~nm}$. During their electrochemical testing, when a constant charge/discharge current was applied, an initial charge capacity of $148 \mathrm{mAh} \mathrm{g}^{-1}$ and a discharge capacity of $135 \mathrm{mAh} \mathrm{g}^{-1}$ were observed with a good cycle life without any distinct capacity loss over 10 cycles. ${ }^{46}$ The synthesis process for this material (in comparison to other synthesis techniques) was shortened to a period of eight hours. This process improved the preparation of the materials in comparison to the normally batch synthesis, positively contributing to time efficiency and improved cycle life.

Further investigations were performed on the cathode material using doping and coating to improve the material's electrochemical behaviour further. One of these investigations was doping with $\mathrm{Zr}$ using ultrasonic spray pyrolysis. ${ }^{50} \mathrm{LiCo}_{1-x} \mathrm{Zr}_{x} \mathrm{O}_{2}$ was prepared by making a $0.5 \mathrm{~mol} \mathrm{~L}^{-1}$ solution consisting of $\mathrm{Li}$, $\mathrm{Co}$ and $\mathrm{Zr}$ nitric salts. The produced solution was atomized at $1.67 \mathrm{MHz}$ into a two-stage heating zone (at 400 and $800{ }^{\circ} \mathrm{C}$ ) quartz reactor. The product was calcined at $900^{\circ} \mathrm{C}$ for 20 hours in a furnace using air. ${ }^{50} \mathrm{~A} 1 \mathrm{~mol} \% \mathrm{Zr}$-doped material produced a pure spinel layered structure. Increasing the $\mathrm{Zr}$-doped concentration showed a decrease in the $1 \mathrm{C}$ discharge capacity. These results were summarized in Table 1 . As the discharge rate was increased, the capacity typically decreased (summarized in Table 2).

From these results, it was concluded that $\mathrm{Zr}$ doping improved both cycling stability and rate performance comparatively. The expansion of the unit cell's lattice distance to allow the extraction/insertion of the $\mathrm{Li}^{+}$ion upon discharge/charge respectively explained the improvements. ${ }^{50}$ The only shortfall in this study
Table 1 Summary of results of the materials' capacity compared to the change in $\mathrm{Zr}$-doped concentration.

\begin{tabular}{cc}
\hline Zr-concentration & Capacity $/ \mathrm{mAh} \mathrm{g}^{-1}$ \\
\hline $\mathrm{x}=0.005$ & 143 \\
$\mathrm{x}=0.01$ & 139 \\
$\mathrm{x}=0.05$ & 135 \\
\hline
\end{tabular}

Table 2 Summary of results of the materials' capacity compared to the change in discharge rate.

\begin{tabular}{cc}
\hline C-rate & Capacity $/ \mathrm{mAh} \mathrm{g}^{-1}$ \\
\hline $0.2 \mathrm{C}$ & 176 \\
$0.5 \mathrm{C}$ & 161 \\
$1 \mathrm{C}$ & 148 \\
3C & 100 \\
\hline
\end{tabular}

was adding and increasing the $\mathrm{Zr}$ content by more than $1 \mathrm{~mol} \%$, as it developed into a secondary phase $\left(\mathrm{Li}_{2} \mathrm{O}_{3}\right) .^{50}$

The preparation of a lithium cobalt oxide material with both $\mathrm{Mn}$ and $\mathrm{Ni}$ as dopants to form $\mathrm{Li}_{1.2} \mathrm{Mn}_{0.54} \mathrm{Ni}_{0.13} \mathrm{Co}_{0.13} \mathrm{O}_{2}$ showed the versatility of the spray pyrolysis method in synthesizing cathode oxides. ${ }^{51}$ The $\mathrm{Mn}$ and Ni-doped lithium cobalt oxide material was synthesized by making a $2.5 \mathrm{M}$ aqueous nitrate solution that contained $\mathrm{LiNO}_{3}, \mathrm{Mn}\left(\mathrm{NO}_{3}\right)_{2} \cdot 4 \mathrm{H}_{2} \mathrm{O}, \mathrm{Ni}\left(\mathrm{NO}_{3}\right)_{2} \cdot 6 \mathrm{H}_{2} \mathrm{O}$ and $\mathrm{Co}\left(\mathrm{NO}_{3}\right)_{2} \cdot 6 \mathrm{H}_{2} \mathrm{O}$ in the right proportions. The prepared solution was sprayed (with the aid of an ultrasonic nebulizer) at $2.4 \mathrm{MHz}$ into a preheater $\left(\right.$ at $\left.200^{\circ} \mathrm{C}\right)$ with a water-saturated air carrier gas (at a flow rate of $6.6 \mathrm{~L} \mathrm{~min}^{-1}$ with a residence time of $6 \mathrm{sec}$ ). The precursor powder was placed in a temperature-controllable 3 -zone vertical furnace reactor where the reactor wall temperatures were kept at 350,575 or $650{ }^{\circ} \mathrm{C}$, respectively. The cooled powder was collected on a porous polycarbonate membrane filter for further analysis and cell preparation. ${ }^{51}$ A robust synthesis method was required to prepare the cathode oxide materials for lithium-ion batteries. Most synthesis methods (such as solidstate combustion and freeze drying) were challenging as they 
required long reaction times, they contained material impurities and batch-to-batch inconsistencies which caused obstructions in the large-scale implementation. The synthesis technique used for this material showed that the variable reactor temperature effect was important, as the primary particle's size influenced the electrochemical performance significantly. A material with a decrease in its primary particle stimulated the electrochemical activation as well as an increase in capacity. In this study, the reactor temperature varied between 350,575 and $800{ }^{\circ} \mathrm{C}$, respectively. At $350{ }^{\circ} \mathrm{C}$, a large particle size was observed because the material was hygroscopic with traces of unreacted $\mathrm{LiNO}_{3}$. Above $575^{\circ} \mathrm{C}$, the nitrate salts reacted completely during the synthesis process. However, the crystallinity of the material increased with improved primary particle growth by increasing the heat of the material from 800 to $900{ }^{\circ} \mathrm{C}$ at shorter time intervals. For cycling and rate capability tests, a discharge capacity that ranged between 162 and $206 \mathrm{mAh} \mathrm{g}^{-1}$ was observed after 100 cycles at a $\mathrm{C} / 3$ rate. ${ }^{51}$ This study (following spray pyrolysis) showed improvements in the batch-to-batch consistency, phase pure materials and cathode materials that produced excellent electrochemical performance.

The electrochemical properties of $\mathrm{LiCoO}_{2}$ could improve by coating the particles with glassy lithium boron oxide (LBO) during the flame spray pyrolysis process. ${ }^{52}$ This type of coating was used in the current study because it had a high $\mathrm{Li}^{+}$content and conductivity. The wetting properties of the coating were good with a relatively low viscosity. The synthesis process consisted of a $1.5 \mathrm{M}$ aqueous nitrate solution that contained $\mathrm{LiNO}_{3}$ and $\mathrm{Co}\left(\mathrm{NO}_{3}\right)_{2} \cdot 6 \mathrm{H}_{2} \mathrm{O}$ dissolved in distilled water, $\mathrm{LiNO}_{3}$ and boric acid $\left(\mathrm{H}_{3} \mathrm{BO}_{3}\right)$ were used for the $\mathrm{Li}_{2} \mathrm{O}-2 \mathrm{~B}_{2} \mathrm{O}_{3}$ glass coating material. This solution was pumped (at a $5 \mathrm{~L} \mathrm{~min}^{-1}$ flow rate) with an $\mathrm{O}_{2}$ carrier gas (at a $10 \mathrm{~L} \mathrm{~min}^{-1}$ flow rate) into a high-temperature diffusion flame. The produced precursor droplets evaporated, decomposed and melted in the diffusion flame. The produced precursor particles were calcined at 500,600 and $700{ }^{\circ} \mathrm{C}$, respectively for three hours in air. The $\mathrm{LBO}$ glass-coated $\mathrm{LiCoO}_{2}$ produced a particle size with a mean of about $54 \mathrm{~nm}$, which was slightly larger than the pure $\mathrm{LiCoO}_{2}$ of about $42 \mathrm{~nm}$. The coated material and the pure $\mathrm{LiCoO}_{2}$ showed lower charge and discharge capacities before calcination (Table 3 ).

Table 3 The initial capacities of $\mathrm{LiCoO}_{2}$ and $\mathrm{LBO}$ glass modified $\mathrm{LiCoO}_{2}$ $(10 \mathrm{wt} \%)$.

\begin{tabular}{|c|c|c|}
\hline & $\mathrm{LiCoO}_{2}$ & $\begin{array}{l}\text { LBO glass } \\
\text { modified } \\
\mathrm{LiCoO}_{2}\end{array}$ \\
\hline Initial charge capacity $/ \mathrm{mAh} \mathrm{g}^{-1}$ & 97 & 83 \\
\hline Initial discharge capacity $/ \mathrm{mAh} \mathrm{g}^{-1}$ & 79 & 74 \\
\hline Discharge capacity after 10 cycles $/ \mathrm{mAh} \mathrm{g}^{-1}$ & 62 & 66 \\
\hline
\end{tabular}

These materials' crystallinity and electrochemistry improved by post-treating the pure $\mathrm{LiCoO}_{2}$ and the $\mathrm{LBO}$ glass modified $\mathrm{LiCoO}_{2}$ at temperatures between 500 and $700{ }^{\circ} \mathrm{C}$. When the pure $\mathrm{LiCoO}_{2}$ and the $\mathrm{LBO}$ glass modified $\mathrm{LiCoO}_{2}$ materials were calcined at $600^{\circ} \mathrm{C}$, an improvement was observed in the material's discharge capacity, decreasing from 119 to $85 \mathrm{mAh} \mathrm{g}^{-1}$ (for pure $\mathrm{LiCoO}_{2}$ ) and 122 to $109 \mathrm{mAh} \mathrm{g}^{-1}$ (for the LBO glass modified $\mathrm{LiCoO}_{2}$ ) upon cycling (55 cycles). From the results, it was concluded that coating the active material's particles increased the mean particle size, showing an improvement in the material's electrochemical properties (such as improved charge/discharge capacities and good cycle properties) and decreasing the material's reactivity in an acidic electrolyte..$^{52}$
The spray pyrolysis synthesis method was also applied successfully to make manganese spinel cathode material. ${ }^{53} \mathrm{~A}$ big advantage of the technique was that a small particle size could be achieved when the final dried solid $\mathrm{LiMn}_{2} \mathrm{O}_{4}$ powder, made from the spray technique, obtained particles that ranged between 75 and $1250 \mathrm{~nm} .{ }^{54}$ Taniguchi et al. ${ }^{47}$ also studied the synthesis of $\mathrm{LiMn}_{2} \mathrm{O}_{4}$ by the spray pyrolysis and drying system. According to their study, the X-ray diffraction analysis showed a pure crystalline material that was cubic spinel in structure, and the SEM analysis showed that the particles were spherical and in some cases, hollow. The charge/discharge curves showed distinct plateaus corresponding to well-defined $\mathrm{LiMn}_{2} \mathrm{O}_{4}$ structures, indicating the characteristics of a spinel manganese oxide structure. Their electrochemical analysis results were summarized in Table 4.

Table $4 \mathrm{LiMn}_{2} \mathrm{O}_{4}$ capacity results after continuous cycling and at various discharge rates.

Discharge capacity/mAh g ${ }^{-1}$

$\begin{array}{lr}\text { 1st cycle at } 0.1 \mathrm{C} & 126 \\ \text { After } 99 \text { cycles at } 0.1 \mathrm{C} & 100 \\ \text { At } 10 \mathrm{C} & 74\end{array}$

After 99 capacity cycles an irreversible capacity loss of $12 \%$ was reported. ${ }^{47}$ An increase in rate also produced a slight change in discharge capacity, which was a result of slow lithium-ion diffusion, but it was still producing a relatively high discharge capacity. Following this method showed good cycle and high rate performances.

The manganese spinel cathode material, $\mathrm{LiMn}_{2} \mathrm{O}_{4}$, experienced capacity fading during cycling, therefore doping contributed to the improvement of cycling performance. These doping elements included $\mathrm{B}, \mathrm{Co}, \mathrm{Fe}, \mathrm{Cu}, \mathrm{Al}$ and $\mathrm{Cr}$ to mention only a few. ${ }^{55-59}$ The doped $\mathrm{LiM}_{x} \mathrm{Mn}_{2-\mathrm{x}} \mathrm{O}_{4}$ material was made by using an aqueous solution that contained nitric salts of the respective dopants with an approximately $0.9 \mathrm{M}$ total metal-ion concentration with tartaric acid for a $\mathrm{pH}$ control between 1 and $1.7 .{ }^{55,59}$ The prepared precursor solution was atomized by an ultrasonic nebulizer (frequency ranging from 1.3 to $1.75 \mathrm{MHz}$ ). The solution was sprayed into air (at a flow rate of $500 \mathrm{~mL} \mathrm{~min}^{-1}$ ) in an electric furnace that was preheated to $800{ }^{\circ} \mathrm{C}$. Solvent evaporation took place within the heating reactor and produced the final oxide particles with a residence time of about $9.4 \mathrm{sec}^{55-59}$

The boron-doped, $\mathrm{LiB}_{x} \mathrm{Mn}_{2-\mathrm{x}} \mathrm{O}_{4}$, phases were studied at different concentration ranges where $x=0.1-0.4$. When $X$-ray diffraction was done, pure crystalline spherical morphology was observed, whereby these spherical morphologies decreased as the boron concentration increased. ${ }^{55}$ However, SEM analysis showed porous and hollow particles except for the high boron concentration materials contributing to the submicron size of mainly all the materials. Having these small particle sized materials for lithium batteries would result into higher charge/discharge rates and short diffusion paths. Electrochemical analysis results showed a significant decrease in the first discharge capacity as provided in Table 5.

The boron-doped material, $\mathrm{LiB}_{0.3} \mathrm{Mn}_{1.77} \mathrm{O}_{4}$, retained up to $82 \%$ of its capacity after 50 cycles at the $0.5 \mathrm{C}$ rate. ${ }^{55}$ Although the material showed a decrease in the first discharge capacity, an improvement in the material's structural stability was observed upon capacity cycling. The results obtained in this study met the industry requirements because the materials produced good cycling performance and capacity. 
Table 5 Summarized electrochemical analysis for $\mathrm{LiB}_{x} \mathrm{Mn}_{2-x} \mathrm{O}_{4}$.

Substitution levels Discharge capacities at $0.5 \mathrm{C} / \mathrm{mAh} \mathrm{g}^{-1}$

$\begin{array}{ll}0.1 & 53 \\ 0.2 & 62 \\ 0.3 & 92 \\ 0.4 & 50\end{array}$

Cobalt-substituted $\mathrm{LiMn}_{2} \mathrm{O}_{4}$ samples were studied by heating the sample at $750{ }^{\circ} \mathrm{C}$ for various time intervals (1, 4 and 8 hours) by the ultrasonic spray pyrolysis process. Their structural analysis showed spherical single spinel-phase particles that ranged in crystallite sizes (summarized in Table 6). ${ }^{56}$ This structural behaviour (crystallinity increase) resulted in an increase in the first discharge capacity (refer to Table 6) with a decrease in irreversible capacity loss over the first cycles (below $10 \%$ ).

Table 6 Crystallite sizes and first discharge capacities of cobaltsubstituted $\mathrm{LiMn}_{2} \mathrm{O}_{4}$ at various time intervals.

\begin{tabular}{lccc}
\hline & 1 hour & 4 hours & 8 hours \\
\hline Crystallite size $/ \mathrm{nm}$ & 39.6 & 52 & 58.9 \\
1st discharge capacity $/ \mathrm{mAh} \mathrm{g}^{-1}$ & 107 & 108 & 113 \\
\hline
\end{tabular}

The cobalt-substituted $\mathrm{LiMn}_{2} \mathrm{O}_{4}$ material was also studied at various $C$-rates ranging from $1 \mathrm{C}$ to $60 \mathrm{C}$. At higher rates $(60 \mathrm{C})$, the sample that was prepared at four hour time intervals resulted in better capacity retention ( $87 \%$ ) when compared to the capacity at $0.1 \mathrm{C}$ rate. The spray pyrolysis process was followed for this material at four hour time intervals which showed an improvement in the electrochemical performance at high rates, whereby the crystallinity was well controlled. ${ }^{56}$

Taniguchi et al. ${ }^{60}$ studied $\mathrm{LiMn}_{2} \mathrm{O}_{4}$ with its substituted form $\mathrm{LiM}_{1 / 6} \mathrm{Mn}_{11 / 6} \mathrm{O}_{4}(\mathrm{M}=\mathrm{Co}, \mathrm{Al}$ and $\mathrm{Ni}$ ) synthesized by ultrasonic spray pyrolysis. The ultrasonic spray pyrolysis synthesis method involved making an aqueous nitrate solution $\left(0.45 \mathrm{~mol} \mathrm{dm}^{-3}\right.$ in concentration). The solution was generated into a mist by an ultrasonic vibrator with a flow of air (flow rate of $2 \mathrm{dm}^{-3} \mathrm{~min}^{-1}$ ) into an electric furnace, (the mist was kept in the furnace for $4.8 \mathrm{~min}$ ) to dry and complete the pyrolysis process. The produced materials' crystallite sizes with its specific area were summarized in Table 7. The spray pyrolysis synthesis route was followed and $\mathrm{LiAl}_{1 / 6} \mathrm{Mn}_{11 / 6} \mathrm{O}_{4}$ and $\mathrm{LiMn}_{2} \mathrm{O}_{4}$ porous microstructure particles were developed whereas $\mathrm{LiCo}_{1 / 6} \mathrm{Mn}_{11 / 6} \mathrm{O}_{4}$ and $\mathrm{LiNi}_{1 / 6} \mathrm{Mn}_{11 / 6} \mathrm{O}_{4}$ showed a smooth surface.

The electrochemistry results of these materials showed two

Table 7 Morphology and electrochemical properties of the metal substituted $\mathrm{LiMn}_{2} \mathrm{O}_{4}$ materials.

$\begin{array}{ll}\text { Crystallite size } / \mathrm{nm} & 28-33 \\ \text { Surface area } / \mathrm{m}^{2} \mathrm{~g}^{-1} & 5.7-12.7 \\ \text { Initial capacity } / \mathrm{mAh} \mathrm{g}^{-1} & 101-117\end{array}$

voltage plateaus at approximately 4.05 and $4.1 \mathrm{~V}$. However, the substituted metal-ions showed lower initial capacities (refer to Table 7) compared to the pure $\mathrm{LiMn}_{2} \mathrm{O}_{4}\left(129 \mathrm{mAh} \mathrm{g}^{-1}\right)$ due to the decrease in $\mathrm{Mn}^{3+}$ ions in $\mathrm{LiMn}_{2} \mathrm{O}_{4}$. An improvement in the capacity retention was observed whereby $\mathrm{LiMn}_{2} \mathrm{O}_{4}$ had an $85 \%$ increase in capacity retention by following the spray pyrolysis process compared to a $75 \%$ capacity retention by following the solid-state process ${ }^{60}$.

Over the years, $\mathrm{LiMn}_{2} \mathrm{O}_{4}$ was used as a suitable cathode material for lithium-ion batteries. However, this material also experienced a few disadvantages of which capacity fading was one of the main drawbacks especially at elevated temperatures. Capacity fading was suppressed by the addition of $\mathrm{AlPO}_{4}$ to the electrolyte. Bakenov et al. ${ }^{61}$ studied this electrolyte's alteration by following the spray pyrolysis technique. They prepared the spinel material by atomizing the precursor solution (an aqueous $0.9 \mathrm{~mol} \mathrm{dm}^{-3}$ total cation solution) at $1.7 \mathrm{MHz}$ with an ultrasonic nebulizer. The sprayed droplets with airflow were carried into the reactor $\left(\right.$ at $800^{\circ} \mathrm{C}$ ) where the solvent evaporated, dried and pyrolyzed forming the solid oxide particles. Thereafter, the particles were collected by means of an electrostatic precipitator at $150{ }^{\circ} \mathrm{C} . \mathrm{AlPO}_{4}$ was added to the electrolyte (1:1), stirred for 24 hours and thereafter the solid $\mathrm{AlPO}_{4}$ phase was separated from the electrolyte by means of the centrifuge technique. The powder X-ray diffraction analysis showed pure single-cubic spinel structures. From the electrochemical results it was observed that the materials' capacity fade decreases with an increase in temperature. At $60^{\circ} \mathrm{C}, 50 \%$ of the materials capacity was lost (after 50 cycles). However, with the addition of $\mathrm{AlPO}_{4}$ a capacity loss of $28 \%$ was observed at $60{ }^{\circ} \mathrm{C}^{61}$ An improvement in the materials' capacity fading was observed by adding $\mathrm{AlPO}_{4}$ especially at high temperatures.

Another new development in this spinel structure was that $\mathrm{LiMn}_{2} \mathrm{O}_{4}$ particles were coated to improve the electrochemical performance in the cathode oxide material. The effects included the dissolution of the electrode material that was in contact with the electrolyte, with side reactions on the electrode's surface and the crystal structure's instability contributing to shortening the battery's capacity life. The particles of $\mathrm{LiMn}_{2} \mathrm{O}_{4}(\mathrm{LMO})$ could be coated with lithium boron oxide glass (LMO-LBO) and $\mathrm{TiO}_{2}$ $\left(\mathrm{LMO}-\mathrm{TiO}_{2}\right)$ by a spray pyrolysis process. ${ }^{62}$ The spray pyrolysis process involved dissolving $\mathrm{Li}, \mathrm{Mn}$ and boron precursors and atomizing them into droplets. These droplets were exposed to a heated reactor where the $\mathrm{Li}$ reacted with the $\mathrm{Mn}$ to form $\mathrm{LiMn}_{2} \mathrm{O}_{4}$ and upon evaporating the solvent, a reaction between $\mathrm{Li}$ and $\mathrm{B}$ occurred to produce the LBO glass phase. The preparation of a core-shell structure by the one-step spray pyrolysis method occurred where the substance, with a higher melting point, tended to bond at the core, while the substance with a lower melting point would be 'pushed' outwardly forming the coating layer $^{62}$ as illustrated in Fig. 4.

The cathode material $\mathrm{LiMn}_{2} \mathrm{O}_{4}$ coated with $\mathrm{Li}_{2} \mathrm{O}-2 \mathrm{~B}_{2} \mathrm{O}_{3}$ glass showed an improvement in its initial capacity of $131 \mathrm{mAh} \mathrm{g}^{-1}$ with an $86 \%$ retention after 100 cycles at the $1 \mathrm{C}$ rate, in comparison to the uncoated $\mathrm{LiMn}_{2} \mathrm{O}_{4}$ producing a $80 \%$ capacity retention (after 100 cycles at $1 \mathrm{C}$ ). ${ }^{6} \mathrm{LiMn}_{2} \mathrm{O}_{4}$ coated with $\mathrm{TiO}_{2}$ had an initial capacity of $126 \mathrm{mAh} \mathrm{g}^{-1}$ with an $86 \%$ retention after 170 cycles at the $1 \mathrm{C}$ rate. ${ }^{62}$ The coated synthesis route enhanced or improved the materials' structural stability and prevented the active materials' dissolution during cycling.

$\mathrm{LiFePO}_{4}$ prepared by spray pyrolysis ${ }^{48}$, produced spherical, hollow, non-agglomerated, narrow particle sizes of 200 to 400 $\mathrm{nm}\left(\right.$ at $500^{\circ} \mathrm{C}$ ) according to the SEM analysis. However, X-ray diffraction analysis showed a mixed amorphous/crystalline sample (at $500{ }^{\circ} \mathrm{C}$ with traces of $\mathrm{Li}_{3} \mathrm{Fe}_{2}\left(\mathrm{PO}_{4}\right)_{3}, \mathrm{Fe}_{2} \mathrm{O}_{3}$ and $\mathrm{SiO}_{2}$ [ from the quartz tube of the reactor] phases) resulting in heating the sample more at 600 to $800{ }^{\circ} \mathrm{C}$ for six hours. This annealed heat-treated material produced non-spherical hollow particles with a foam-like appearance and larger particle sizes. ${ }^{48}$ Nanostructured particles prepared by spray pyrolysis (which was achieved in this study) resulted into shorter $\mathrm{Li}^{+}$ion diffusion lengths and a reduced ohmic drop, enhancing the electrochemical performance (higher capacities at higher rates). ${ }^{48}$ 


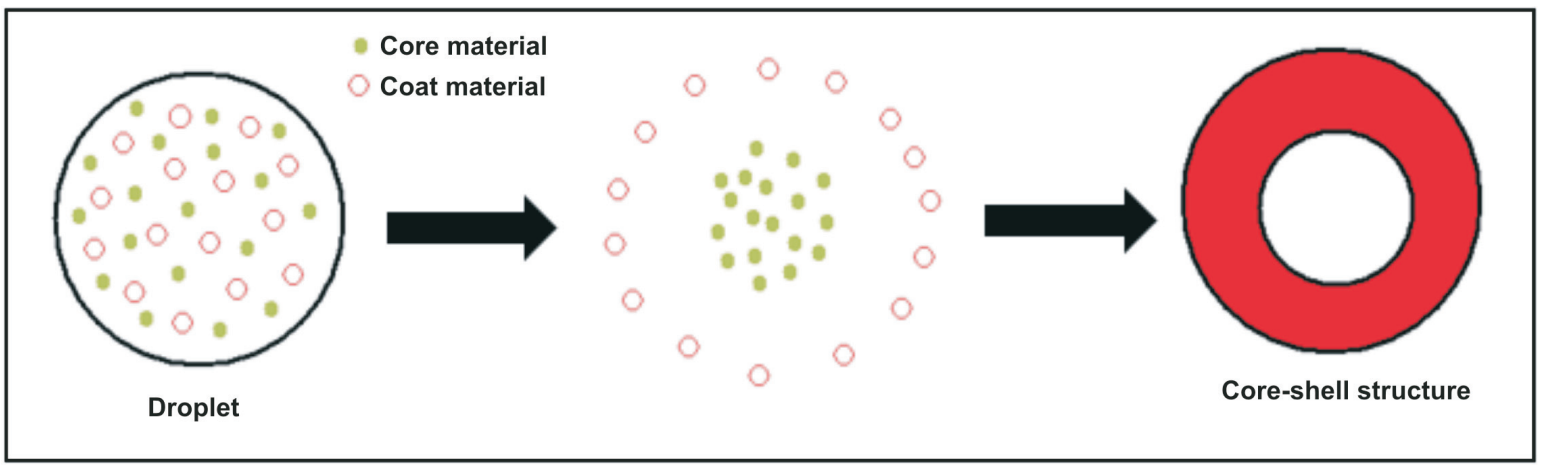

Figure 4 Schematic diagram on the formation of a core-shell structure.

The structural, morphological and electrochemical performance of $\mathrm{LiFePO}_{4}$ cathode materials was improved by doping and coating them using similar spray pyrolysis. ${ }^{62-65}$ The material was doped with transition metals such as $\mathrm{Ni}, \mathrm{Co}, \mathrm{Mg}$ and other metals that are still being investigated. ${ }^{9,63} \mathrm{Mg}$-doped $\mathrm{LiFePO}_{4}$ synthesized by the spray pyrolysis method involved using diluted nitric acid where $\mathrm{Li}_{2} \mathrm{CO}_{3}, \mathrm{NH}_{4} \cdot \mathrm{H}_{2} \mathrm{PO}_{4}, \mathrm{FeC}_{2} \mathrm{O}_{4} \cdot 4 \mathrm{H}_{2} \mathrm{O}$ and $\mathrm{Mg}\left(\mathrm{C}_{2} \mathrm{H}_{3} \mathrm{O}_{2}\right)_{2} \cdot 4 \mathrm{H}_{2} \mathrm{O}$ were dissolved to make up the precursor solution. ${ }^{63}$ The solution was pumped into a furnace (at $400{ }^{\circ} \mathrm{C}$ ) with the aid of Ar as the carrier gas. A cyclone collected the produced precursor powder, which was further calcined at $750{ }^{\circ} \mathrm{C}$ for 10 hours. ${ }^{63}$ Wang et al. ${ }^{63}$ studied the effect of Mg-doped $\mathrm{Li}_{1-\mathrm{x}} \mathrm{Mg}_{\mathrm{y}} \mathrm{FePO}_{4}$ at various stoichiometric amounts $(\mathrm{x}=0.97,0.98$, 0.99 and $y=0.005,0.01,0.02)$. X-ray diffraction analysis showed a pure single olivine-doped structure and the SEM analysis showed the crystallized powders with an average particle size of between 1 and $2 \mu \mathrm{m}$. The result was a material that had a higher electronic conductivity by four orders of magnitude when compared to the undoped $\mathrm{LiFePO}_{4}$ material. ${ }^{63}$ The initial charging capacity was higher than its discharge capacity, which could be due to $\mathrm{LiFePO}_{4}$ producing a large surface area by the spray pyrolysis synthesis. Further investigations were done on this material due to its poor electrochemical results which could be improved by optimizing the sintering procedure which could lead to obtaining optimal crystals and improved electrochemical performance $^{63}$.

A two-step carbon coating and spray pyrolysis process prepared $\mathrm{LiFe}_{0.6} \mathrm{Mn}_{0.4} \mathrm{PO}_{4} / \mathrm{C} .{ }^{65}$ Firstly carbon coating was prepared by dissolving the appropriate starting materials with sucrose in ethanol. The mixture was ball milled for three hours, dried under vacuum at $100{ }^{\circ} \mathrm{C}$ for two hours and heated in a furnace for three hours at $550{ }^{\circ} \mathrm{C}$ under $\mathrm{N}_{2}$. The second process involved ball milling in the water of the pre-sintered product, polyethylene glycol (PEG400 as a dispersant), sucrose and multiwall carbon nanotubes (MWCNT) for five hours producing a suitable slurry. The slurry was sprayed to form an aerosol, resulting in the formation of spherical powdered particles after the moisture had evaporated. The spray-dried product was annealed at $650{ }^{\circ} \mathrm{C}$ for 10 hours under $\mathrm{N}_{2}$, forming pure $\mathrm{LiFe}_{0.6} \mathrm{Mn}_{0.4} \mathrm{PO}_{4} / \mathrm{C}$. The characterization of the product showed pure spherical oxide particles (5-20 $\mu \mathrm{m}$ in size) and a carbon layer of about $3 \mathrm{~nm}$. This was a comparative study of $\mathrm{LiFe}_{0.6} \mathrm{Mn}_{0.4} \mathrm{PO}_{4} / \mathrm{C}$ and $\mathrm{LiFe}_{0.6} \mathrm{Mn}_{0.4} \mathrm{PO}_{4} / \mathrm{C}$ with MWCNT. The surface area of the material was $22.36 \mathrm{~m}^{2} \mathrm{~g}^{-1}$ and the electrochemical tests showed a discharge capacity of $163.3 \mathrm{mAh} \mathrm{g}^{-1}$ at $0.1 \mathrm{C}$ rate $\left(\mathrm{LiFe}_{0.6} \mathrm{Mn}_{0.4} \mathrm{PO}_{4} / \mathrm{C}\right.$ with MWCNT). This result was an improvement of the electrochemical performance, whereby bare $\mathrm{LiFe}_{0.6} \mathrm{Mn}_{0.4} \mathrm{PO}_{4} / \mathrm{C}$ could still deliver a capacity of $12.8 \mathrm{mAh} \mathrm{g}^{-1}$ at $50 \mathrm{C}$, and $\mathrm{LiFe}_{0.6} \mathrm{Mn}_{0.4} \mathrm{PO}_{4} / \mathrm{C}$ with MWCNT could deliver a capacity of
$64.23 \mathrm{mAh} \mathrm{g}^{-1}$. Furthermore, $\mathrm{LiFe}_{0.6} \mathrm{Mn}_{04} \mathrm{PO}_{4} / \mathrm{C}$ with MWCNT microspheres was promising for use in large-scale applications (such as electric vehicles). ${ }^{65}$

\section{Conclusion}

This brief review of the spray pyrolysis through sol-gel materials for Li-ion cathode materials showed the versatility of the ability to prepare a number of doped and coated materials that could range in particle size, crystalline characteristics and material properties. In this study, it was observed that a spray pyrolysis method produced micro to submicrometre particles effectively, as well as particles with narrow particle size distributions and homogeneous particles in a continuous step, which was controllable in a short time period. These parameters contributed to optimize the electrochemical properties (making it possible to still obtain reasonable capacity at high rates) in terms of the achievable discharge capacities and capacity cycle durability. The use of a spray pyrolysis method resulted in a decreased use of expensive reagents/compounds (cost effective), it lowered solvent use, improved temperature control, and workplace safety because of the decrease in harmful materials to which workers could be exposed. The spray pyrolysis synthesis process could be considered as a suitable technique for large-scale pilot plant cathode materials, concluding that the technique met the industrial requirements or specifications. In this study, the spray pyrolysis through sol-gel materials was followed to obtain the materials' best results.

\section{Acknowledgements}

The authors thank Nelson Mandela Metropolitan University (NMMU) and the South African National Research Foundation (NRF) for their financial contribution and the Johannes Gutenberg University (JGU), Mainz, for experimental assistance throughout the study.

\section{References}

1 Energizer Report, Nickel Metal Hydride (NiMH), Handbook and Application Manual, 2010.

2 B.C.H. Steele, eds., Fast Ion Transport in solids: Solid-state Batteries and Devices, North-Holland/American Elsevier Inc., AmsterdamLondon/New York, 1973.

3 J. Yamaki, Advances in Lithium-Ion Batteries, (W.A. van Schalkwijk and B. Scrosati, eds.), Kluwer Academic/Plenum Publishers, New York, 2002, pp. 155-183.

4 S.S. Zhang, A review on the separators of liquid electrolyte Li-ion batteries, J. Power Sources, 2007, 164, 351-364.

5 V. Palomares, T. Rojo, Synthesis process for Li-ion battery electrodes from solid state reaction to solvothermal self-assembly methods, in Lithium ion batteries - New developments, (I. Belharouak, ed.), InTech, Croatia Europe, 2012.

6 Q. Lui, S. Wang, H. Tan, Z. Yang and J. Zeng, Preparation and doping 
mode of doped $\mathrm{LiMn}_{2} \mathrm{O}_{4}$ for Li-ion batteries, Energies, 2013, 6, 1718-1730.

7 T. Ohzuku and A. Ueda, Solid-state redox reactions of $\mathrm{LiCoO}_{2}(\mathrm{R} 3 \mathrm{~m})$ for 4 volt secondary lithium cells, J. Electrochem. Soc., 1994, 141, 2972-2977.

8 T. Cui, N. Hua, Y. Han and X. Kang, Preparation and electrochemical properties of $\mathrm{LiMn}_{2} \mathrm{O}_{4}$ by a rheological-phase-assisted microwave synthesis method, Inorg. Mater., 2008, 44, 542-548.

9 Y. Zhang, Q. Huo, P. Du, L. Wang, A. Zhang, Y. Song, Y. Lv and G. Li, Advances in new cathode material $\mathrm{LiFePO}_{4}$ for lithium-ion batteries, Synth. Met., 2012, 162, 1315-1326.

10 J. Gim, J. Song, D. Nguyen, M.H. Alfaruqi, S. Kim, J. Kang, A.K. Rai, V. Mathew V and J. Kim, A two-step solid state synthesis of $\mathrm{LiFePO}_{4} / \mathrm{C}$ cathode with varying carbon contents for Li-ion batteries, Ceram. Int., 2014, 40, 1561-1567.

11 H.S. Kim, D.W. Kam and W.S. Kim, Synthesis of $\mathrm{LiFePO}_{4}$ by a solid-state reaction using organic acids as a reducing agent, Ionics, 2011, 17, 293-297.

12 L.J. Fu, H. Liu, C. Li, Y.P. Wu, E. Rahm, R. Holze and H.Q. Wu, Electrode materials for lithium secondary batteries prepared by sol-gel methods, Prog. Mater Sci., 2005, 50, 881-928.

13 M.A. Aegerter and M. Mennig, eds., Sol-Gel Technologies for Glass Producers and Users, Springer Science \& Business Media, New York, 2004.

14 G.G. Avci and D. Abanoz, Corrosion protection of steel by hybrid sol-gel coating, Eng. Mater., 2004, 264-268, 387-390.

15 A.U. Jarza, D. Andrzejewski, K. Maruszewski, H. Podbielska and W. Strek, Advantages of sol-gel technologies for biomedical applications, P. Soc. Photo-opt. Ins., 1999, 50.

16 PR Newswire Report, Sol-Gel Processing of Ceramics and Glass, New York, July (2014)

17 L. Predoana, A. Barau, M. Zaharescu, H. Vasilchina, N. Velinova, B. Banov and A. Momchilov, Advanced techniques for $\mathrm{LiCoO}_{2}$ preparation and testing, International Workshop, Advanced Techniques for Energy Sources Investigation and Testing, September P4, 2004, 1-7.

18 I.H. Oh, S.A. Hong and Y.K. Sun, Low-temperature preparation of ultrafine $\mathrm{LiCoO}_{2}$ powders by sol-gel method, J. Mater. Sci., 1997, 32, 3177-3182.

19 M.V. Reddy, T.W. Jie, C.J. Jafta, K.I. Ozoemena, M.K. Mathe, A.S. Nair, S.S. Peng, M.S. Idris, G. Balakrishna, F.I. Ezema and BVR. Chowdari, Studies on bare and $\mathrm{Mg}$-doped $\mathrm{LiCoO}_{2}$ as a cathode material for Lithium ion Batteries, Electrochim. Acta, 2014, 128, 192-197.

20 P. Prahasini, M. Sivakumar, R. Subadevi and F.M. Wang, Synthesis and characterization of $\mathrm{Cu}$ doped $\mathrm{LiCoO}_{2}$ cathode material for lithium batteries using microwave assisted sol-gel synthesis, Adv. Mater. Res., 2012, 584, 345-349.

21 S. Valanarasu, R. Chandramohan, R.M. Somasundaram and S.R. Srikumar, Structural and electrochemical properties of Eu-doped $\mathrm{LiCoO}_{2}$, J. Mater. Sci., 2011, 22, 151-157.

22 C. Julien, L. El-Farh, S. Rangan and M. Massot, Studies of LiNi0.6Co0.4O2 cathode material prepared by the citric acid-assisted sol-gel method for lithium batteries, J. Sol-Gel Sci. Technol., 1999, 15, 63-72.

23 C. Li, H.P. Zhang, L.J. Fu, H. Lui, Y.P. Wu, E. Rahm, R. Holze and H.Q. Wu, Cathode materials modified by surface coating for lithium ion batteries, Electrochim. Acta, 2006, 51, 3872-3883.

24 B.J. Hwang, R. Santhanam and D.G. Liu, Characterization of nanoparticles of $\mathrm{LiMn}_{2} \mathrm{O}_{4}$ synthesized by citric acid sol-gel method, J. Power Sources, 2001, 97-98, 443-446.

25 Y.K. Sun, Synthesis and electrochemical studies of spinel $\mathrm{Li}_{1.03} \mathrm{Mn}_{2} \mathrm{O}_{4}$ cathode materials prepared by a sol-gel method for lithium secondary batteries, Solid State Ionics, 1997, 100, 115-125.

26 Y. Lee, Y. Sun and K. Nahm, Synthesis of spinel $\mathrm{LiMn}_{2} \mathrm{O}_{4}$ cathode material prepared by an adipic acid-assisted sol-gel method for lithium secondary batteries, Solid State Ionics, 1998, 109, 285-294.

27 P. Singh, A. Sil, M. Nath and S. Ray, Preparation and characterization of lithium manganese oxide cubic spinel $\mathrm{Li}_{1.03} \mathrm{Mn}_{1.97} \mathrm{O}_{4}$ doped with $\mathrm{Mg}$ and Fe, Physica B, 2010, 405, 649-654.

28 Y. Lee, Y. Sun and K. Nahm, Synthesis of spinel $\mathrm{LiMn}_{2} \mathrm{O}_{4}$ cathode material prepared by an adipic acid-assisted sol-gel method for lithium secondary batteries, Solid State Ionics, 1998, 109, 285-294.

29 X. He, L. Wang, W. Pu, G. Zhang, C. Jiang and C. Wan, Synthesis of spinel $\mathrm{LiMn}_{2} \mathrm{O}_{4}$ for Li-ion batteries via sol-gel, Inter. J. Electrochem. Sci., 2006, 1, 12-16.

30 R. Thirunakaran, A. Sivashanmugam, S. Gopukumar, C.W. Dunnill and D.H. Gregory, Studies on chromium/aluminium-doped manganese spinel as cathode materials for lithium-ion batteries - A novel chelated sol-gel synthesis J. Mater. Process. Technol., 2008, 208, 520-531.

31 X. Huang, M. Lin, Q. Tong, X. Li, Y. Ruan and Y. Yang, Synthesis of $\mathrm{LiCoMnO}_{4}$ via a sol-gel method and its application in high power $\mathrm{LiCoMnO} / \mathrm{Li}_{4} \mathrm{Ti}_{5} \mathrm{O}_{12}$ lithium-ion batteries, J. Power Sources, 2012, 202, 352-356.

32 C.Y. Li, B.W. Sing, Y. Zheng, Z.Q. Chao and S. Zhi, Electrochemical performance Ni doped spinel $\mathrm{LiMn}_{2} \mathrm{O}_{4}$ cathode for lithium ion batteries, Adv. Mater. Res., 2012, 347-353, 290-300.

33 T.F. Yi, Y.R. Zhu, X.D. Zhu, J. Shu, C.B. Yue and A.N. Zhou, A review of recent developments in the surface modification of $\mathrm{LiMn}_{2} \mathrm{O}_{4}$ as cathode material of power lithium-ion battery, Ionics, 2009, 15, 779-784.

34 G.X. Wang, S. Needham, J. Yao, J.Z. Wang, R.S. Liu and H.K. Liu, A study on $\mathrm{LiFePO}_{4}$ and its doped derivatives as cathode material for lithium-ion batteries, J. Power Sources, 2006, 159, 282-286.

35 H. Karami and F. Taala, Synthesis, characterization and application of $\mathrm{Li}_{3} \mathrm{Fe}_{2}\left(\mathrm{PO}_{4}\right)_{3}$ nanoparticles as cathode of lithium-ion rechargeable batteries, J. Power Sources, 2011, 196, 6400-6411.

36 J.K. Kim, J.W. Choi, G.S. Chauhan, J.H. Ahn, G.C. Hwang, J.B. Choi and H.J. Ahn, Enhancement of electrochemical performance of lithium iron phosphate by controlled sol-gel synthesis, Electrochim. Acta, 2008, 53, 858-8264.

37 D. Jugovic and D. Uskokovic, A review of recent developments in the synthesis procedure of lithium iron phosphate powders, J. Power Sources, 2009, 190, 538-544.

38 M.C. Rao, Vanadium pentoxide cathode material for fabrication of all solid state lithium-ion batteries, Res. J. Recent Sci., 2013, 2, 67-73.

39 M.Y. Saidi, J. Barker, H. Huang, J.L. Swoyer and G. Adamson, Performance characteristics of lithium vanadium phosphate as a cathode material for lithium-ion batteries, J. Power Sources, 2003, 119-121, 266-272.

40 X.J. Zhu, Y.X. Liu, L.M. Geng and L.B. Chen, Synthesis and performance of lithium vanadium phosphate as cathode materials for lithium ion batteries by a sol-gel method, J. Power Sources, 2008, 184, 578-582.

41 J.W. Fergus, Recent developments in cathode materials for lithium ion batteries, J. Power Sources, 2010, 195, 939-954.

42 Y.H. Jouybari and S. Asgari, Synthesis and electrochemical properties of $\mathrm{LiNi}_{0.8} \mathrm{Co}_{0.2} \mathrm{O}_{2}$ nanopowders for lithium ion battery applications, J. Power Sources, 2011, 196, 337-342.

43 C. Arpagaus, N. Schafroth and M. Meuri, Buchi Report, Laboratory Scale Spray Drying of Lactose, 2010, 57.

44 A. Gharsallaoui, G. Roudaut, O. Chambin, A. Voilley and R. Saurel, Applications of spray-drying in microencapsulation of food ingredients, Food Res Int., 2007, 40, 1107-1121.

45 T. Penovic, A. Sander and V. Grozdanic, Spray drying of aqueous solutions of inorganic and organic materials, Part. Sci. Technol., 2013, $31.5,458-465$.

46 Y. Li, N.P. Haigh, C. Wan, Y. Wu, C. Jiang and Y. Zhu, Synthesis and characterization of ultrafine $\mathrm{LiCoO}_{2}$ powders by a spray-drying method, J. Power Sources, 2000, 85, 294-298.

47 I. Taniguchi, N. Fukuda and M. Konarova, Synthesis of spherical $\mathrm{LiMn}_{2} \mathrm{O}_{4}$ microparticles by a combination of spray pyrolysis and drying method, J. Power Sources, 2008, 181, 228-236.

48 L.S. Gomez, I. de Meatza, M.I. Martin, M. Bengoechea, I. Cantero and M.E. Rabanal, Morphological, structural and electrochemical properties of lithium iron phosphate synthesized by spray pyrolysis, Electrochim. Acta, 2010, 55, 2805-2809.

49 K. Amine, S. Ban and R.M. Nault, News from Argonne's Transportation Technology RED Center, 2009, Report 9.

50 S.H. Kim and C.S. Kim, Improving the rate performance of $\mathrm{LiCoO}_{2}$ by Zr doping, J. Electroceram, 2009, 23, 254-257.

51 M. Lengyel, G. Atlas, D. Elhassid, P.Y. Luo, X. Zhang, I. Belharouak and R.L. Axelbaum, Effects of synthesis conditions on the physical and electrochemical properties of $\mathrm{Li}_{1.2} \mathrm{Mn}_{0.54} \mathrm{Ni}_{0.13} \mathrm{Co}_{0.13} \mathrm{O}_{2}$ prepared by spray pyrolysis, J. Power Sources, 2014, 626, 286-296.

52 S.H. Choi, J.H. Kim, Y.N. Ko, K.M. Yang and Y.C. Kang, Preparation 
and electrochemical properties of glass-modified $\mathrm{LiCoO} 2$ cathode powders, J. Power Sources, 2013, 244, 129-135.

53 S. Hirose, T. Kodera and T. Ogihara, Synthesis and electrochemical properties of $\mathrm{Li}$-rich spinel type $\mathrm{LiMn}_{2} \mathrm{O}_{4}$ powders by spray pyrolysis using aqueous solution of manganese carbonate, J. Alloys Compd., 2010, 506, 883-887.

54 B. Ebin, V. Battaglia and S. Gurmen, Comparison of $4 \mathrm{~V}$ and $3 \mathrm{~V}$ electrochemical properties of nanocrystalline $\mathrm{LiMn}_{2} \mathrm{O}_{4}$ cathode particles in lithium ion batteries prepared by ultrasonic spray pyrolysis, Ceram. Int., 2014, 40, 7029-7035.

55 B. Ebin, G. Lindbergh and S. Gurmen, Preparation and electrochemical properties of nanocrystalline $\mathrm{LiB}_{\mathrm{x}} \mathrm{Mn}_{2}{ }^{-} \mathrm{O}_{4}$ cathode particles for Li-ion batteries by ultrasonic spray pyrolysis method, J. Alloys Compd., 2015, 620, 399-406.

56 C.H. Lu, T.Y. Wu, H.C. Wu, M.H. Yang, Z.Z. Gua and I. Taaniguchi, Preparation and electrochemical characteristics of spherical spinel cathode powders via an ultrasonic spray pyrolysis process, Mater. Chem. Phys., 2008, 112, 115-119.

$57 \mathrm{I}$. Taniguchi and Z. Bakenov, Spray pyrolysis synthesis of nanostructured $\mathrm{LiFe}_{\mathrm{x}} \mathrm{Mn}_{2}{ }^{-} \mathrm{O}_{4}$ cathode materials for lithium-ion batteries, Powder Technol., 2005, 159, 55-62.

58 B. Ebin, S. Gurmen and G. Lindbergh, Preparation and electrochemical properties of spinel $\mathrm{LiFe}_{\mathrm{x}} \mathrm{Cu}_{\mathrm{y}} \mathrm{Mn}_{1.2} \mathrm{O}_{4}$ by ultrasonic spray pyrolysis, Ceram. Int., 2014, 40, 1019-1027.
$59 \mathrm{I}$. Taniguchi, Powder properties of partially substituted $\mathrm{LiM}_{x} \mathrm{Mn}_{2-x} \mathrm{O}_{4}$ $(\mathrm{M}=\mathrm{Al}, \mathrm{Cr}, \mathrm{Fe}$ and $\mathrm{Co})$ synthesized by ultrasonic spray pyrolysis, Mater. Chem. Phys., 2005, 92, 172-179.

60 I. Taniguchi, D. Song and M. Wakihara, Electrochemical properties of $\mathrm{LiM}_{1 / 6} \mathrm{Mn}_{11 / 6} \mathrm{O}_{4}(\mathrm{M}=\mathrm{Mn}, \mathrm{Co}, \mathrm{Al}$ and $\mathrm{Ni})$ as cathode materials for Li-ion batteries prepared by ultrasonic spray pyrolysis method, J. Power Sources, 2002, 109, 333-339.

61 Z. Bakenov, M. Wakihara and I. Taniguchi, Battery performance of nanostructured lithium manganese oxide synthesized by ultrasonic spray pyrolysis at elevated temperature, J. Solid State Electrochem., 2008, 12, 57-62.

62 D. Jung, Y. Ko, Y. Kang and S. Park, Recent progress in electrode materials produced by spray pyrolysis for next-generation lithium ion batteries, Adv. Powder Technol., 2014, 25, 18-31.

63 G.X. Wang, S.L. Bewlay, K. Konstantinov, H.K. Liu, S.X. Dou and J.H. Ahn, Physical and electrochemical properties of doped lithium iron phosphate electrodes, Electrochim. Acta, 2004, 50, 443-447.

$64 \mathrm{~J}$. Wang and X. Sun, Understanding and recent development of carbon coating on $\mathrm{LiFePO}_{4}$ cathode materials for lithium-ion batteries, Energy Environ Sci., 2012, 5, 5163-5185.

65 Y. Mi, P. Gao, W. Liu, W. Zhang and H. Zhou, Carbon nanotubeloaded mesoporous $\mathrm{LiFe}_{0.6} \mathrm{Mn}_{0.4} \mathrm{PO}_{4} / \mathrm{C}$ microspheres as high performance cathodes for lithium-ion batteries, J. Power Sources, 2014, 267, $459-468$. 